\title{
MARIA COLOMBO TIMELLI, Les distiques proverbiaux dans la «Geste de Monglane»... et dans «Beuve d'Hantone» en prose
}

\section{Elisabetta Barale}

\section{(2) OpenEdition}

1 Journals

\section{Édition électronique}

URL : https://journals.openedition.org/studifrancesi/22372

DOI : 10.4000/studifrancesi.22372

ISSN : 2427-5856

Éditeur

Rosenberg \& Sellier

\section{Édition imprimée}

Date de publication : 1 avril 2020

Pagination : 155

ISSN : 0039-2944

\section{Référence électronique}

Elisabetta Barale, « maria colombo timelLı, Les distiques proverbiaux dans la «Geste de Monglane»... et dans «Beuve d'Hantone» en prose », Studi Francesi [En ligne], 190 (LXIV | I) | 2020, mis en ligne le 01 avril 2020, consulté le 03 août 2021. URL : http://journals.openedition.org/studifrancesi/22372 ; DOI https://doi.org/10.4000/studifrancesi.22372

Ce document a été généré automatiquement le 3 août 2021

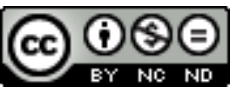

Studi Francesi è distribuita con Licenza Creative Commons Attribuzione - Non commerciale - Non opere derivate 4.0 Internazionale. 


\title{
MARIA COLOMBO TIMELLI, Les distiques proverbiaux dans la «Geste de Monglane»... et dans «Beuve d'Hantone» en prose
}

\author{
Elisabetta Barale
}

\section{RÉFÉRENCE}

MARIA COLOMBO TIMELLI, Les distiques proverbiaux dans la «Geste de Monglane»... et dans «Beuve d'Hantone» en prose, “Le Moyen Âge” CXXIV, 2018/1, pp. 119-144.

1 L'A. mène une comparaison entre les proverbes insérés dans la Geste de Monglane (ms. Paris, BnF, Arsenal, 3351) et dans Beuve d'Hantone en prose (ms. Paris, BnF, fr. 12554). Après avoir remarqué que ces deux copies présentent plusieurs affinités concernant tant la mise en page que les modalités d'insertion des distiques, elle aborde la question des sources et démontre que les deux prosateurs ont fait recours aux Proverbes moraux de Christine de Pizan, bien que généralement ils n'empruntent pas les mêmes distiques. En particulier, le rédacteur de la Geste de Monglane cite à l'identique quatorze proverbes de Christine et en remanie trente-quatre pour mieux les adapter à son contexte narratif et à la langue de son époque; l'adaptateur de Beuve d'Hantone ne partage avec lui que sept proverbes, dont il fournit d'ailleurs une version plus proche du texte christinien. Puisqu'au total les deux ouvrages reprennent les trois-quarts des Proverbes, l'A. constate que le recueil de Christine a circulé en milieu bourguignon dans la seconde moitié du $\mathrm{XV}^{\mathrm{e}}$ siècle et avance l'hypothèse que l'un des prosateurs aurait pu connaître le travail de l'autre. 